\title{
Plan and Policies for Success in the Business World: A Conceptual Study
}

\author{
Md. Asraful Alam ${ }^{1}$, Md. Motaharul Islam ${ }^{2}$ \\ ${ }^{1}$ Senior Administrative Officer, ASA University Bangladesh, BANGLADESH \\ ${ }^{2}$ Associate Professor in Management, Open School, Bangladesh Open University, BANGLADESH
}

\begin{abstract}
Bangladesh is a land of opportunity. The individual has the opportunity to obtain an education, to select his occupation, and to make progress in his chosen work. Bangladesh is a country where many people are working. More than one of every ten persons in our nation is employed. While opportunities for employment are almost unlimited, the happiest workers are those who have learned a trade or a profession, who are successful in working with others and who are efficient producers. Each worker who strives to do his best gains much personal satisfaction from his employment helps produce goods and services at reasonable prices and contributes to the welfare of his community and his nation.
\end{abstract}

Key Words: Employment; Success; Bangladesh

\section{INTRODUCTION}

If we drop out of school today, to what kind of job could we look forward? Many employers would not care to interview us if we were not a high school or college graduate. And if we did get a job, we would find that our opportunities were limited. Perhaps we are eager to get started and to earn some money. But a job that looks good to us at 16 is likely to be disappointing to us at 26. Many who have dropped out of school have learned that promotions are usually given to those who are prepared for them. Plan knows to prepare our self for work that we will like and that will give us a satisfactory income.

Perhaps we may have already decided that we want to become a salesman, a composer, a teacher, a nurse, a farmer, a physician, a mechanic, or an engineer. Or we may still be undecided and may be thinking about several different kinds of work. Whatever our decision may be, we will want to plan for the future. Such planning will pay in money and in personal satisfaction. It will require:

- That we study our own interests and ability.

- That we learn as much as possible about the job or jobs in which we are interested.

- That we match our interests and abilities with the job requirements.

- That we then consider the kind of training we will need.

\section{KNOW OUR SELF}

Consider first what we like to do. Since the work we do will account for a large part of our life, our happiness will depend to a great extent upon how much we enjoy our work. 
People generally do best the things they enjoys doing. Here are some questions we should ask our self:

Do we like detail work?

Do we enjoy working with others?

Do we prefer to work along?

Do we like to work outdoors?

Do we prefer indoor work?

Do we like to make things?

Do we like to read?

Do we like to travel?

Are we interested to be our own boss some day, or would we prefer working for someone else?

Now think of the abilities and the skills that we have. Almost all of us can do several things satisfactorily, but most of us are able to do certain kinds of things better than we can do others. Ask our self these questions:

Do we speak with ease in front of groups?

Can we sing or play a musical instrument?

Are we good in sports?

Do we draw picture well?

Do we like mathematics?

Do we have the know-how to repair an engine, a computer, or a tv?

Are we a good writer?

Another good way to prepare an estimate of our abilities is to study our school record.

What is our answer to these questions?

Do we do equally well in all subjects?

What are our hardest subjects?

What are our easiest subjects?

In what subjects would we like to do additional study?

Do we want to take college courses?

Hobbies sometimes reveal special interests and abilities. Among the hobbies that may have vocational values are gardening, sewing, cooking, amateur radio operating, reading, and making model airplanes. Some people have made lifetime careers from hobbies that they had when they were young. While in school we will have the opportunity to take special kind of tests. Among these are reading ability tests, general ability tests, interest inventories and various kinds of aptitude tests. Take as many of these tests as we can. They will show some of ours strong and weak points any will give us a further indication of our interests and abilities. But do not expect tests alone to tell us what we should or should not do. Tests are merely one of the many devices that we can use. Consult our teachers and counselors for information about tests that we can take and how they should be interpreted.

We will also need to consider our health, physical strength, and endurance. Some occupations require more physical energy than others. For example, the work of engineers, farmers, and construction workers often requires more than average physical strength. Some occupations require certain physical proportions. As an example, airline hostesses must not be over a certain height.

We will make a wiser choice of our occupation if we will make a careful study of our interests, abilities, and physical qualities. We will want to avoid preparing for a physical quality. We will want to avoid preparing for an occupation for which we do not have the necessary personal qualities for which we do not want to spend the required years of study. 


\section{KNOW ABOUT OCCUPATIONS}

Most people work for a total of about 40 years. Since people are now living longer than previously, very likely this period of work will become linger, think of these questions.

What do I want to be doing 15 or 20 years from now?

What beginning jobs should I seek?

What education should I have to reach this occupational goal?

No one begins at the top. A plant foreman may have spent many years as an apprentice or as a skilled worker. A school superintendent may have served as a teacher or a principal for many years. A secretary may have worked as a file clerk, typist, or a stenographer. The owner of your grocery store probably worked as a clerk in a store or as a sales man for a long period of time. We can gather occupational information in many ways. Consult our teachers and counselors for information and advice. Check with our school and public librarian for books, pamphlets, and magazines containing information about job opportunities and job requirements. Obtain similar information from local employment offices.

Visit a factory, a farm, a store, an office, or other places where people work at occupations in which you are interested. Observe what these workers are doing. Arrange an interview with a person who is working at a job we think we would enjoy doing. Learn about the job requirements and the training needed. Seek the opinions of our parents and friends. Be on the alert for job information that we may get from newspapers and radio and television programs. Our government publishes several excellent booklets about occupations. Our local public employment office will have copies of these publications, and our local library may also have them. The job Guide for Young Workers gives facts about jobs most frequently held by young people leaving high school. The Occupational outlook Handbook contains employment information about more than 200 occupations. Each of the Armed Forces- Army, Navy, and Air Force publishes an Occupational Handbook pointing up career and training possibilities in the services and the civilian jobs for which this training qualifies you.

A widely used government publication is the Dictionary of Occupational Titles. It lists over 2,000 specific ways of earning a living. Examine this Dictionary, since by doing so we may discover some occupations in which we are interested but which we did not know existed. It is also of value in describing the duties involved in particular occupations.

Make full use of as many sources as we can, and get all the information we can, since choosing our lifework is one of the most important decisions we will ever make.

\section{We MUST DECIDE}

The wise person selects his occupation. He avoids drifting form one job to another hoping that some day the right job will come along. The wise person studies his abilities and interests; he studies the requirements of jobs in which he is interested; and then he matches the two. No one can tell us exactly what occupation to follow. We will want to get complete information about the occupation and about our self and then decide.

We may not be ready to select now the specific job we want to do, but we can begin thinking about the field of work we would like to enter. As we gather more information and gain more experience, we will be able to narrow down our job choices.

\section{Preparing for our Profession}

If we have a general idea of our occupational goal, we can plan our school studies to help we prepare for it. For example, if we are planning for a business occupation after 
completing high school, we will want to make as many choices as program will permit from such subjects as bookkeeping, typewriting, shorthand, office practice business machines, salesmanship, retailing, business law, economics, and business . If we expect to prepare for an occupation that requires education beyond high school, we should study the requirements of the college or other school that we may wish to enter.

If we are planning to enter a homemaking, or an agricultural occupation, we may want to take courses in one of these fields. If we decided to follow a general college preparatory source, we may want to take courses in one of the vocational fields. A few practical courses may make it easier for us to secure a part-time job to help pay our college expenses. While in high school do not overlook the extracurricular activities. Besides being enjoyable, they may contribute to the success of our future work. If we want to be teacher, a lawyer, or a politician, or if we hope to engage in other work that requires speaking before groups, take part in debates and forum discussions. Sports will help us to keep healthy and to learn to get along with others. Taking part in music, dramatic, art, photography clubs and in publishing our school newspaper any offer valuable background experience for future success in our life's work. Experience as an officer of a club or a chairman of a committee well helps us be more confident and poised when we work with others. Do not underestimate the value of our high school record. Employers are likely to examine it very carefully. Frequently teachers and school officials are asked to fill out rating sheets about us and the quality of our work. Our high school record is also considered by colleges that we may wish to enter. To a pro specie employer of a college admissions officer, our school grades indicate our ability to learn. Our school record is a permanent record; it is important for us to establish the best record in our life.

\section{A PLEASING PERSONALITY IS NEEDED}

What do we mean when we say that "She has a pleasing personality," or "His personality needs to be improved" Personality is hard to define because it can mean different things to different people. In a practical sense, personality consists of the qualities that make an impression on others. And this impression is based largely on their qualities: one's appearance, one's voice, and one's behavior. In planning for successful employment it is important to eliminate any undesirable qualities that we may have and to develop or strengthen those desirable qualities that will create favorable impressions.

\section{IMPRESSIONS ARE INFLUENCED BY ONE'S APPEARANCE}

Our appearance can create either a favorable or an unfavorable first impression. Before we apply for a position, check our appearance completely. Note how we stand and how we walk. Take an inventory of our clothes. Are they appropriate for the occasion- for the job, for recreation, for a social affair? Our clothes need not be new or expensive. But they should fit; they should be in good taste; and they should not be flashy and poorly matched. More important, they should be clean and neat. Nest, check on personal cleanliness. There is no excuse for unkempt hair, stained teeth, or unclean skin. A favorable appearance can be developed by good posture, by good taste in what one wears, and by good grooming.

\section{IMPRESSIONS ARE INFLUENCED BY ONE'S SPEECH}

A pleasing voice is an asset on the job and in personal life. If we want people to listen to us, make it pleasant for them to do so. No one enjoys listening to a voice that is too loud, too high-pitched, or too weak to be heard. It is within our power to cultivate our speech so 
that we can make better impressions upon those who hear us. Speech difficulties such as stuttering, stammering, and lisping can be corrected by specialists.

A good voice is of little value if we are careless in the use of our language. Carelessness in pronouncing words and making errors in grammar often indicate that one is careless in other things as well. There are times when slang expressions and catch phrases are permissible; but do not get into the habit of saying "OK," "sure," "yeah," "nope," and similar overused expressions. With the increased use of telephones, radio, television, and public address systems, we are becoming more conscious of voice and speech. Television advertisers select announcers who have pleasant voices. We are attracted by want they say. We are amused by the mistakes that they make. None of us ever learns to speak perfectly; but unless we constantly try to improve our speech, poor speech habits develop and we leave unfavorable impressions. Even our great leaders, including preside specialists in order to learn how to speak more effectively.

\section{IMPRESSIONS ARE INFLUENCED BY ONE'S BEHAVIOR}

An attractive appearance and a pleasant voice will cause a favorable reaction in others, but the good impressions we make can be canceled by improper and thoughtless behavior. Let us consider some of the favorable actions and attitudes that can help make our place in life more satisfying and rewarding.

Be honest: One would think that this important quality is so obvious that is need not be mentioned. "Of course," we say, "everybody should be honest." But young people in business sometimes forget that certain undesirable habits are forms of dishonest. For example, do you consider the following people really honest:

A person who frequently reports late for work, but who continues to draw the same pay as those who work full time? A clerk who habitually extends the 15-minute "tea break" to a half hour or more? A customer who knowingly keeps overpayment of change received form a salesman? A man who, before selling his old car, fills it with extra heavy oil in an attempt to conceal worn rings or loose valves? An office worker who often uses the business telephone for personal calls? A secretary who discusses the shortcomings of her boss in public, yet continues to pretend that she is loyal to him? A student who copies his homework or cheats on tests because others do it?

No one can consider completely honest if he is honest in most things but is dishonest in little things that he thinks may not harm anyone.

Be dependable: If we can answer "Yes" to the following questions, we are developing the important quality of dependability.

Do we finish jobs that we start?

Do we keep our promises?

Are we on time for work? for class? for appointments?

If it is impossible for us to keep an appointment with a dentist, a teacher, or anyone else, do you notify that person?

If we agree to serve on a committee or to held a class office, can we be depended upon to do our share of the work?

Be cooperative: A football team would get nowhere without the cooperation of each of the eleven players. A television show would fail without the full cooperation of actors, announcers, cameramen, lighting technicians, and others. An assembly line in a factory will turn out a poor product if even one worker fails to do his job properly. 
There are few jobs where one can do everything by himself; teamwork is a key to success in the office, the store or the factory.

Be thoughtful: We are thoughtful if we have regard for the interests and the welfare of others and if we are consider of their feelings. Give aid to those less fortunate than you. Be a good listener and show an interest in the activities of others. Congratulate friends on their achievements. Avoid gossiping about others. Do not make fun of the limitations of others. Don't pry into other people's personal affairs.

Use good manners: Good manners can add to your business success and social popularity. Knowing how to do the right thing makes you feel at ease and avoids embarrassment. Do you know, for example, that:

When a young man calls for a young lady at her house, he goes to the door; he does not sit in his car in front of the house and sound his horn.

In introductions, men are presented to women and young people are presented to older people: Mrs. Nargish, may I present Mr. Rafi", "Dr. Saad, I should like to have you know my school chum, Redowan", Mother, this is Md. Rafi."

During introductions a man does not offer to shake hands with a lady unless she first extends her hand.

While traveling or while eating in restaurants, it is customary to supporters, bellboys, and waitresses. In general, 10 to 15 per cent or the bill is considered a reasonable tip in good restaurants. In a theater a lady removes a large hat so that people sitting behind her will not have their view obstructed.

Men open doors of buildings and cars for ladies and elderly people.

There are many other forms of proper behavior that are easy to follow. Keep learning about accepted practices; it is generally easier to do the right thing than the wrong thing.

\section{DeVelop Good Work HaBITS}

Now is the time to start developing good work habits and proper attitudes. In our schoolwork, plan our time, organize our class assignments, and have work ready when it is due. If we do baby-sitting, report to this duty on time, know what to do in the event of an emergency, and do more than may be expected. If we have a temporary job, work as carefully as if we expected to be employed permanently. The efficient work habits we develop now may mean the difference between success and failure in the future.

\section{WORK EXPERIENCE IS A STEPPINGSTONE TO JOB SUCCESS}

While we are in school, spare-time and vacation jobs can provide valuable experience as well as needed money to help pay for school and living expenses. Whenever possible, obtain employment that is related to the kind of work you may want to do in the future. For example, we want to be an accountant, try to obtain work as a clerk in an accounting from, in a bank, or in the payroll, purchasing, or credit department of a business. If salesmanship is our goal, seek experience as a salesclerk in a department store. At Christmas time we might work in the toy department or in the gift- wrapping section. Or we might obtain employment as a soda fountain attendant or as a door-to door salesman. Duties that bring we into contact with the public will provide valuable background experience for future success in selling. Regardless of the kind of part-time job you obtain, be a careful observer of successful workers on the job in which we are 
interested you will thus gain a better picture of the job requirements and of the personal qualities needed for success on the job.

\section{HOW TO LOOK FOR JOBS}

When you are ready for employment, do not be satisfied with taking the first job that comes along. Seek the best available job by taking advantage of the sources of help that are listed below. Most of these suggestions will also be of value to us if we look for part-time of summer employment.

- Select a number of places in which we would like to work and then apply in person. Employers are impressed by the initiative of a young person who is effective in presenting his qualification.

- Tell friends about your desire for work. They may know of opportunities in the places where they work and elsewhere.

- Let our counselors and teachers know of our job needs.

- Register with public and private employment service offices. We can often get counseling and testing assistance from them.

- Study the "want ads" in our local papers and follow up quickly on those openings that interest us. We may also want to run a "Job wanted" advertisement our self.

- Interview business agents or other officials of local unions for information about apprenticeships, job placement services, union membership requirements, and the job market.

- Inquire at our city hall, country seat, or post office about job vacancies, qualification, and examinations that may be given for government work.

\section{OPPORTUNITIES IN BUSINESS}

Whatever we interests in the business field may be, the opportunities are almost unlimited. Completion of a high school program with certain subjects in various business fields, or completion of business of jobs.

The demand for competent office workers in business is high. These workers keep records, operate business machines, do secretarial work, receive and pay out money, type letters, handle telephone messages, plan appointment and travel schedules, file and find business papers, and perform many other special tasks.

Merchandising is another large field of opportunity. Here there is need for stock clerks, retail store clerks, salesmen, shipping department clerks, workers in advertising departments, and many others. Not business could operate without maintenance and general workers of many kinds. These include janitors, repairmen, elevator operators, drivers, assembly line workers, cafeteria workers, and others.

For those who qualify through successful experience in part-time and beginning jobs and through further training, the opportunities for advancement are promising. Many men and women in management and other top positions in industry started in beginning jobs similar to those described. The worker who advances is prepared for the next higher job, accepts responsibilities, and can be depended upon to get the job done. Good work habits developed on first jobs can prepare the worker for more important responsibilities later on. 


\section{Most People Work as Employees}

Of the more than 2.5 crore of people who work in different jobs in Bangladesh, only a small proportion are self-employed. Among those who are self- employed are farmers; owners of small businesses; craftsmen, such as plumbers, electricians, and painters; and professional workers, such as doctors, dentists, lawyers and engineers. But most workers are serving a employees of a business, of a government department, or of some other organization. As good citizens, therefore, we need to understand some of the problem (1) of businessmen in selecting and placing workers in jobs that they can do best; and (2) of employees in getting along with their employers and with their fellow employees.

\section{EMPLOYERS MATCH EMPLOYEE WITH JOB REQUIREMENTS}

When an employer has a job to fill, he must select from a number of applicants the person he believes to be best qualified for the job. In a small business the proprietor himself may hire an employee, explain the duties of the job, and train him to do the job. In a large business the duties of various jobs are studied by experts so that the requirements of each job are clearly defined. then when a worker applies for a job, his personal qualities and abilities are compared with the job requirements. Most large businesses employ a personnel director or an employment manager whose responsibility is to study the duties of various jobs and to place the best available applicants in these jobs.

\section{The Good Citizen Gets ALONG With Employer}

The success of any organization that employs depends greatly upon the efficiency, the cooperation, and the loyalty of its employees. An employer cannot operate a business with success by paying for services of employees who do unsatisfactory work and who do not earn their pay. For the welfare of a business and the community in which the business is located, employer must choose employees who will be cooperative and productive workers in his organization.

Every conscientious employee desires to make progress in his work. From time to time he will want to discuss employment problems with his employer. In many jobs he may bargain individually with his employer on such matters. In other jobs he may belong to a labor union that acts as his representative in bargaining with his employer. Our government has established by law the right of an employee join a labor union of his own choice and to bargain collectively (as a group) in making agreements about wages, hours of work, or other problems.

Both the employer and the employee depend upon one another to perform business task. The employer wants to hire workers who fit into his organization and who earn their pay. The employee seeks a job that will pay him a satisfactory income and that will give him personal satisfaction.

\section{CONCLUSION}

In almost all jobs we must work with others. In offices, stores, or factories are workers with different educational, religions, racial, and economic backgrounds. This is Bangladeshis democracy at work. While we have not solved all of our problems, Bangladesh can be strong because we have learned to work together. 
When we do our share and often a little more than our share, our fellow workers tend to do likewise, cheerfulness, a cooperative attitude, and good feeling toward others are qualities that help to create pleasant working conditions. Occasions sometimes arise when these qualities are especially important. We may be expected to work overtime to get an important task completed. We may need to do some extra work because of illness of other workers. We may disagree on such minor matters as room temperature, ventilation, and arrangement of furniture and equipment. The arrangement of vacation schedules and the staggering of lunch and tea- break period may cause concern. Discussing such problems with fellow workers and supervisors in a friendly way will usually solve them. Every employee should be interested in the work he is doing. If he is dissatisfied with his job, he should discuss his grievances, either personally or through his union, with his supervisor. Perhaps he is engaged in the wrong kind of work and should seek a transfer to another department of should look for other employment. All workers, from the unskilled laborers to the top executive of an organization, are members of a team. As a working team they are best able to produce the good and the service desired by consumers. Every worker has the responsibility of doing what he can to make his job pleasant and profitable both for himself and for his fellow workers. The good citizen understands many of the problems of the businessman in producing goods and services. The businessman must make decisions about what and how much to produce and about where and how to sell his product. He is faced continuously with the problem of hiring competent workers and in keeping them satisfied on the job. He must find ways to raise money to state a business and to keep it operating; and he must determine what prices to charge for products so that fair wages can be paid and reasonable profits can be made. Our standard of living depends to a large extent on our ability to buy the goods and the services we desire. In order to busy these things, most of us must earn regular incomes. Thus our economic welfare requires that satisfactory employment be available to all qualified workers. The good citizen is therefore concerned about matters that affect working opportunities and conditions. For example, if a strike occurs, employees may be out of work for some time. Businesses may be forced to shut down or toe reduces operations. Shortages caused by lack of production may result in serious inconveniences to consumers as well as increased prices on scarce commodities. As a result, employees, employers, investors, and all of us as consumers may suffer hardships when strikes occur. Our general welfare requires satisfactory relationships between employers and employees. The good citizen understands that our local, state, and federal governments provide services demanded by citizens and these services are paid for out of tax money. He understands that, as the cost of services increases, taxes will necessarily increase; that as citizens we may have whatever government services we wish, but that we must pay for these services. The good citizen will vote intelligently for laws and projects that have merit and for public officials who are honest and dependable.

\section{References}

Abraham,W.(1964).“Saving Patterns in Latin America," Economic Development and Cultural Change, vol.-I.

Ahmed, Muzaffar (1984), Small and Rural Business Management (in Bengali); Journal of the Institute of Business Administration, University of Dhaka, August, 1984, Dhaka.

AndersonYates, M.A.(1991). "Preparing Students for the High Performance work organizationbalancing business training and education," Business education observed, LXIII.75-79. 
Casico, Wayne F.(1973). Managing Human Resources, McGraw Hill International, 2nd Edition.

Deshpande, Monohar U. (1984); "Entrepreneurship of Small Scale Industries: Concept Growth and Management, New Delhi, Deep and Publication.

Goldsmith, R.W. (1969). Financial Structure and Development, Yale University Press, New Haven.

Government of the Peoples Republic of Bangladesh; Bangladesh Economic Survey 2003, (May 2003); Ministry of Finance, Dhaka.

Government of the Peoples Republic of Bangladesh; Statistical Yearbook 2002, Bangladesh Bureau of Statistics, Ministry of Planning, Dhaka.

Graff, M.(2001). "Financial Development and Economic Growth in Corporate and Liberal Market Economics," conference paper, 30th annual conference of economists, Perth, Australia.

Gupta, K. L.(1970). “On some determinants of Rural and Urban household savings Behaviour," American Economic Review, June.

Human Development Report (1996): Published by Oxford University Press, New York.

ILO Analysis (1962); "Role of Small Industry in Economic Development", Productivity, volume3, 1962, Quoted in Deshpande,

Jhingan, M.L (1996); "Entrepreneurship in Economic Development; The Economics of Development and Planning; 29th ed., Konark Publishing Pvt. Ltd., Delhi, p-407-413.

Katz, Robert L.(1991). "Business Classics, 15Key Concepts for Managerial Success," Harvard Business Review , U.S.A.

Kolberg, W.H. and Smith, F.C.(1991).“Rebulding America's workforce-business strategies to close the competitive gape,"Homewood,IL:Business One Irwin.

Levine, R.(1997). “Financial Development and Economic Growth:Views and Agenda,” Journal of Economic Literature,35,pp 688-736.

Mannan M. Abdul (1995); An Introduction to Financial Management, Royal Library, Dhaka.

Mathur, G. (1974). "Choice of Planning Framework", The Indian Economy-Performance Prospects,Dept. of Economics, Bombay, India.

Monohar U. "Entrepreneurship of Small Scale Industries; Concept, Growth and Management; p-29.

Nahapiet, J., and Ghoshal, S.,(1998), Social Capital, Intellectual Capital, and the Organizational Advantage, Academy of Management Review, Vol.23, No. 2, pp. 242-266.

Oliver, S., and Kandadi, R., (2006), How to Develop Knowledge Culture in Organization? A Multiple Case Study of Large Distributed Organizations, Journal of Knowledge Management, Vol. 10, No.4, pp. 6-24.

Papoutsakis, H,(2006), Linking Knowledge Management and Information technology to Business Performance: A Literature Review and A Proposed Model, Journal of Knowledge Management Practices, Vol. 7, No.1, pp. 1-14.

Rus, I., and Lindvall, M., (2002), Knowledge Management in Software Engineering, IEEE Software, Vol. 19, No.3, pp. 26-38.

Schumperter, Joseph A. (1959); The Theory of Economic Development.

Sen,Amartya(1975). Employment, Technology and Development, Clarandon Press, Oxford.

Sikder, Hussian, Zahid (1998); "Small Entrepreneurship Development in Bangladesh; A Study of selected Enterprises in Chittagong", The Chittagong University Journal of Commerce, Vol14, p111-134.

Tulgan, Bruce and Martin, Carolyn (2002), Managing the Generation Mix, HRD Press January.

World Commission on Environment and Development (1988), Our Common Future, Oxford, New York University Press, Printed in Great Britain. 